\title{
CD37 wt Allele
}

National Cancer Institute

\section{Source}

National Cancer Institute. CD37 wt Allele. NCI Thesaurus. Code C102768.

Human CD37 wild-type allele is located in the vicinity of $19 q 13.3$ and is approximately $5 \mathrm{~kb}$ in length. This allele, which encodes leukocyte antigen CD37 protein, plays a role in the modulation of immunoglobulin production. 